\title{
STUDI FITOKIMIA IRVINGIA MALAYANA SEBAGAI ANTIMALARIA DARI HUTAN MERU BETIRI DALAM RANGKA DRUG DISCOVERY
}

\author{
${ }^{1}$ Puspaningtyas, A.R, ${ }^{2}$ Dewi, I.P, ${ }^{3}$ Christmarini, D.M \\ ${ }^{1,2}$ Fakultas Farmasi, Universitas Jember, Jember \\ ${ }^{3}$ Fakultas Kedokteran Gigi, Universitas Jember, Jember \\ email : aixrose_pee@yahoo.co.id
}

\begin{abstract}
ABSTRAK
Pendahuluan : Meru betiri adalah hutan di daerah Kabupaten Jember yang banyak mengandung tanaman obat. Salah satunya adalah tanaman Irvingia malayana (Pauh Kijang) yang telah terbukti berdasarkan penelitian sebagai antimalaria. Tujuan : Penelitian ini adalah suatu pencarian obat baru (Drug Discovery) untuk antimalaria dengan cara mengisolasi akar, batang dan daun tanaman Irvingia malayana dan diuji antimalaria. Metode : Elusidasi struktur menggunakan FTIR, H-NMR, dan GC-MS dari senyawa hasil isolasi. Hasil : Dari hasil elusidasi struktur, senyawa hasil isolasi adalah senyawa terpenoid pada batang yang berasal dari ekstrak etil asetat dan merupakan golongan silimarin seperti halnya tanaman lain dalam genus Irvingia. Jarak lebur isolat Irvingia malayana yaitu 120$121^{\circ} \mathrm{C}$ berbentuk kristal putih. Pada Uji in vivo berdasarkan statistik menunjukkan bahwa masing masing kelompok berbeda bermakna. Pada hari 4 setelah pemberian menunjukkan $\mathrm{IC}_{50}$ yaitu $11,827 \mathrm{mg} / \mathrm{kgBB}$ dibandingkan hari $3(6,927 \mathrm{mg} / \mathrm{kgBB})$. Oleh karena itu pada hari ke 3 adalah maksimal lama pemberian yang memberikan efek maksimum daripada hari selanjutnya dalam menurunkan plasmodiumnya dan menunjukkan sangat baik aktivitasnya sebagai antimalaria. Dari hasil uji in vitro didapatkan $\mathrm{IC}_{50}$ isolat Irvingia malayana yaitu $62,855 \mu \mathrm{g} / \mathrm{ml}$ dan berdasarkan klasifikasinya memiliki aktivitas antiplasmodium lemah jika dibandingkan kontrol positif klorokuin karena $\mathrm{IC}_{50}$ klorokuin $1,114 \times 10^{-3} \mu \mathrm{g} / \mathrm{ml}$. Kesimpulan : Berdasarkan data uji aktivitas in vivo dan in vitro antimalaria menunjukkan bahwa isolat kurang memberikan aktivitas antimalaria dikarenakan pada ekstrak yang terdiri dari komponen yang cukup banyak kemungkinan ada mekanisme sinergisme antimalaria jika dibandingkan senyawa tunggal.
\end{abstract}

Kata Kunci: Antimalaria, irvingia malayana, fitokimia, drug discovery, in vivo, in vitro.

\begin{abstract}
Background : Meru Betiri forest in Jember contains a lot of medicinal plants. Irvingia malayana (Pauh Kijang), which is one of the medicinal plants found, has been proven as an antimalarial. Aims : This study aims to find phytochemical and antimalarial activities of Irvingia malayana isolates. Methods : This study was conducted for an antimalarial Drug Discovery through phytochemical study by isolating the roots, stems, and leaves of Irvingia malayana and analysis using FTIR, H-NMR, and GC-MS. Results : The compound in the ethyl acetate extract of Irvingia malayana stem was concluded a terpenoid that contained silymarin as well as other plants in the genus Irvingia. The melting point of Irvingia malayana isolate was $120-121^{\circ} \mathrm{C}$ with white crystals. In vivo antimalarial study showed that each group was significantly different. On day 4 after administration, $\mathrm{IC}_{50}$ showed was $11,827 \mathrm{mg} / \mathrm{kgBW}$ and day 3 was $6,927 \mathrm{mg} / \mathrm{kgBW}$. Therefore, 3 days is the maximum duration of administration in reducing plasmodium and showed the most excellent activity as antimalarial. In vitro antimalarial study using Plasmodium falcifarum FCR3, IC 50 of Irvingia malayana $(62.855 \mathrm{ug} / \mathrm{ml})$ has weak activity compared to chloroquine as positive controls $\left(\mathrm{IC}_{50}=1,114 \times 10-3 \mathrm{ug} / \mathrm{ml}\right)$. Conclusion : Based on the data of in vivo and in vitro antimalarial activities, the compound had no antimalarial activity because the extract
\end{abstract}


consisted of many components that possessed many possible synergetic mechanisms of antimalarial if compared to single compound.

Keywords: Antimalarial, irvingia malayana, phytochemicals, drug discovery, in vivo, in vitro

\section{PENDAHULUAN}

Malaria merupakan penyakit tropis yang banyak tersebar merata di beberapa kawasan di Indonesia. Daerah endemik malaria terbanyak berada di luar pulau Jawa, dimana masih banyak hutan- hutan tropis di Indonesia yang menjadi daerah rawan malaria. Selama periode 2000 - 2004, angka endemis malaria di seluruh Indonesia cenderung menunjukkan peningkatan. Di Pulau Jawa dan Bali, Annual Parasite Insidence (API) selama periode waktu 1995 2000 per 1000 penduduk meningkat pesat dari 0,07 (1995), 0,08 (1996), 0,12 (1997), 0,30 (1998), 0,52 (1999), dan 0,81 (2000). KLB (Kejadian Luar Biasa) malaria selama periode 1998-2003 telah menyerang di 15 propinsi yang meliputi 84 endemis dengan jumlah penderita 27.000 dengan 368 kematian. Bila dilihat per provinsi dari tahun 2008 - 2009 provinsi dengan API yang tertinggi adalah Papua Barat, NTT dan Papua terdapat 12 provinsi yang diatas angka API nasional (CDC, 2010; Direktorat Pengendalian Penyakit Bersumber Binatang, 2011; WHO, 2011).

Malaria merupakan penyakit yang disebabkan oleh parasit golongan Plasmodium dimana jenis yang sering rentan terjadi resistensi yaitu Plasmodium falcifarum dan menjadi suatu permasalahan tersendiri bagi Indonesia. Upaya yang dapat dilakukan bagi penderita malaria yaitu pengobatan sekaligus pencegahan berupa pemberantasan malaria itu sendiri. Kasus malaria di Indonesia yang menghantui saat ini adalah resistensi Plasmodium terhadap obat klorokuin. Kasus resistensi $P$ falciparum terhadap klorokuin di Indonesia pertama kali dilaporkan pada tahun 1973 di Kalimantan Timur. Sejak itu kasus resistensi dilaporkan semakin meluas. Tahun 1990 dilaporkan telah terjadi kasus resistensi $P$ falciparum terhadap klorokuin di seluruh provinsi di Indonesia. Pengobatan malaria khususnya $P$. falciparum di Indonesia mulai tahun 2004 berdasarkan kebijakan Depkes harus menggunakan obat baru kombinasi derivat artemisinin yang dikenal dengan artemisinin combination therapy (ACT), salah satunya yaitu artesunatamodiakuin (artesdiakuin) sesuai rekomendasi dari WHO. Pengobatan itu sendiri tak lantas membuat kasus malaria terselesaikan seutuhnya, mengingat begitu pesatnya penyebaran wabah (Bunnag dkk, 1997; Santoso, 2011; Syamsudin, 2005; Tjitra E, 2000).

Saat kini telah banyak ditemukan obat antimalaria yang resisten, untuk itu timbul pemikiran kami untuk melakukan penelitian dalam pencarian obat baru (Drug Discovery) yang berasal dari alam untuk digunakan 
sebagai alternatif pengobatan antimalaria. Kekayaan sumber daya alam di Indonesia juga mendorong kami untuk turut mencari solusi bagi pengobatan malaria. Meru betiri adalah hutan di daerah Kabupaten Jember yang banyak mengandung tanaman obat. Salah satunya adalah tanaman Irvingia malayana (Pauh Kijang) yang telah terbukti berdasarkan penelitian sebagai antimalaria. Pauh kijang (Irvingia malayana) telah dimanfaatkan dalam kehidupan sehari-hari antara lain kayunya dimanfaatkan sebagai bahan bangunan sedang lemak dari bijinya digunakan pada pembuatan sabun dan lilin. Selain itu Family Simarubaceae terkenal sebagai obat antimalaria dan Irvingia malayana merupakan salah satu anggotanya yang belum diteliti secara mendalam studi fitokimianya sebagai antimalaria. Pada penelitian yang dilakukan oleh Chairul dan Praptiwi (2008) menggunakan ekstrak dari tanaman Irvingia malayana memberikan pengaruh antimalaria cukup signifikan pada Plasmodium berghei. Informasi ilmiah lainnya menunjukkan bahwa ekstrak metanol daun tumbuhan Pauh Kijang (konsentrasi 10 $\mu \mathrm{g} / \mathrm{mL})$ memiliki efek farmakologi sebagai antimalaria dengan hambatan sebesar 95\% terhadap Plasmodium falciparum FcB1 (Aguiar dkk, 2012; Beourou, 2011; Bero, 2009; Pouplin dan Tran, 2007; Saxena dkk, 2003). Namun studi fitokimia dengan mengisolasi tanaman Irvingia malayana belum pernah dilakukan, sehingga belum diketahui pasti senyawa aktif mana yang bermanfaat sebagai antimalaria (Chinchilla dkk, 2012; , Phillipson dkk, 1995; Chairul dan Praptiwi, 2008; Wright $^{\mathrm{a}}$, 2005; Wright ${ }^{\mathrm{b}}$, 2005)

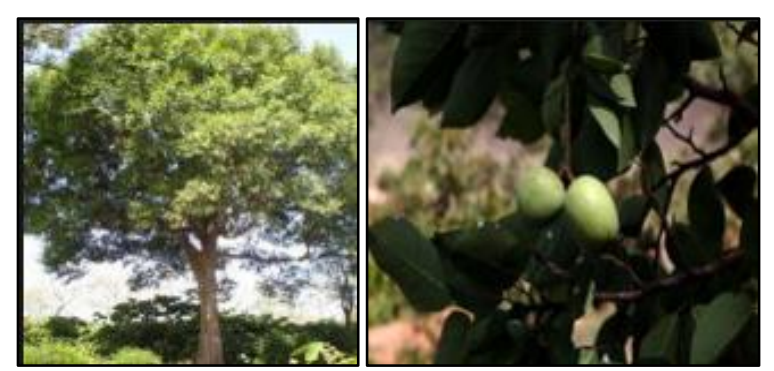

Gambar 1. Tanaman Irvingia malayana Penelitian ini merupakan suatu pencarian obat baru (Drug Discovery) antimalaria melalui studi fitokimia dengan cara mengisolasi akar, batang dan daun tanaman Irvingia malayana untuk mencari lead compounds baru untuk diidentifikasi struktur (FTIR, NMR, dan GCMS) dan diuji aktivitas antimalaria baik in vitro maupun in vivo.

\section{METODE PENELITIAN}

\subsection{Alat}

Timbangan analitik dan hewan, Chamber KLT, lampu UV 254 nm, melting point Electrothermal, Spektrofotometer Resonansi Magnetik Inti: JEOL type JNM ECA $500 \mathrm{Mhz}$, Spektrofotometer FTIR : Shimadzu Type IR Prestige-21, GC-MS Shimadzu, kaca obyek, kaca penutup, Inkubator $\mathrm{CO}_{2} \quad$ (Heraceus), sentrifus (Universal $320 \mathrm{R}$ Hettich), sonikator, laminar air flow cabinet Esco Class II BSC, autoklaf, hemositometer (Nebauer), mikroskop inverted (Olympus $\mathrm{CH}-2$ ), mikroskop 
fluoresensi (Zeiss MC 80), kamera digital (Canon S 40), Mikropipet Biorad, alat suntik, stopwatch, hot plate, termometer.

\subsection{Bahan}

Tanaman dan isolat Irvingia malayana, etanol (Merck), heksan (Merck), etil asetat (Merck), aseton (Merck), eter (Merck), kloroform (Merck), Silika gel 60 F 254 (Merck), toluene (Merck), metanol (Merck), $\mathrm{KBr}$ pro spektrometri, $(\mathrm{CD} 3)_{2} \mathrm{CO}$ (aseton- $\mathrm{d}^{6}$ ) pro NMR, TMS pro NMR, $\mathrm{HCl}$ (Merck), Plasmodium falcifarum FCR3, RBC, minyak emersi, alkohol, CMC Na, Trisodium sitrat, asam sitrat, sorbitol, $\mathrm{NaCl}$, hydrogen peroksidase dalam metanol, RPMI 1640, HEPES, Natrium Bikarbonat 90\%, Hypoxantin, Gentamycin, Serum 10\%, Giemsa 20\% dalam aqua, AlbuMAX II (invitrogen), DMSO (Fluka), $\mathrm{H}_{2} \mathrm{O}$ buffer ( $\mathrm{pH}$ $6,8)$, mencit jantan galur Swiss.

\subsection{Ekstraksi Akar, Batang, Dan Daun Tanaman Irvingia Malayana}

Akar, batang, dan daun Irvingia malayana segar, dikeringkan hingga menjadi simplisia kering dan dibuat serbuk, selanjutnya diekstraksi dengan pelarut etanol $70 \%$, n-heksan, dan etil asetat menggunakan metode perkolasi kemudian dilakukan penguapan pelarut dengan menggunakan rotary evaporator hingga diperoleh ekstrak kasar (Saxena dkk, 2003).

\subsection{Skrining Fitokimia Dari Akar,} Batang, Dan Daun Tanaman Irvingia Malayana
Skrining fitokimia dilakukan bertujuan untuk menentukan golongan metabolit sekunder yang mempunyai aktivitas biologis yang ada dalam akar, batang, dan daun tanaman Irvingia malayana. Analisis yang dilakukan yaitu uji terpenoid karena berdasarkan penelitian antimalaria poten yang berasal dari alam berada pada golongan terpenoid. Ekstrak di tambah eter, kemudian ditetesi $5 \mathrm{~mL}$ asam asetat glasiat ditambah 10 tetes asam sulfat pekat membentuk wama merah atau hijau (Saxena dkk, 2003).

2.5 Fraksinasi Dan Isolasi Akar, Batang, Dan Daun Tanaman Irvingia Malayana

Ekstrak kasar difraksinasi menggunakan kromatografi kolom dengan fase diam silika gel 60 F 254 ukuran 70-230 mesh, dimensi $1 \times 25 \mathrm{~cm}$, dan fase gerak heksan:etil asetat $(10: 1, v / v)$. Fraksi-fraksi ditampung dan dianalisis dengan KLT (Kromatografi Lapis Tipis) dan Rf yang spotnya sama digabungkan, selanjutnya direkristalisasi. Kristal yang terbentuk diuji kemurnian dengan KLT pada berbagai perbandingan eluen dan dilihat resolusinya (Rs), dilanjutkan dengan uji titik leleh dan uji pereaksi Liberman-Buchard serta terakhir elusidasi struktur (Saxena dkk, 2003).

\subsection{Uji Kemurnian Senyawa Hasil Isolasi}

\subsubsection{Kromatografi Lapis Tipis (KLT)}

Noda tunggal menunjukkan senyawa murni jika diamati dengan lampu UV 254 dan 
$366 \mathrm{~nm}$ dengan berbagai perbandingan eluen (Saxena dkk, 2003).

\subsection{Uji Kemurnian Dengan Penentuan Titik Leleh}

Sampel dimasukkan pipa kapiler yang salah satu ujungnya ditutup dan diamati suhu saat sampel mulai melebur sempurna. Kristal dikatakan murni apabila rentang suhu lebur yaitu $\leq 2{ }^{\circ} \mathrm{C}$ (Jayaselli dkk, 2008).

\subsection{Identifikasi Struktur Senyawa Hasil}

Isolasi

\subsubsection{Spektrofotometri Infra Merah}

Sejumlah serbuk sampel dicampur homogen dengan $\mathrm{KBr}$ dan dibuat pellet dengan menekan hidrolik lalu spektrumnya diamati pada bilangan gelombang 4000-400 $\mathrm{cm}^{-1}$ dengan FTIR (Saxena dkk, 2003).

\subsubsection{Spektrofotometri}

1H-Nuclear

\section{Magnetic Resonance}

Sejumlah sampel dipreparasi dengan dilarutkan dalam kloroform-d1 $\left(\mathrm{CDCl}_{3}\right)$, dengan standar internal tetrametilsilan (TMS) kemudian diletakkan di tempat sampel di antara dua kutub dan disinari dengan gelombang radio. Spektrum NMR ialah grafik dari banyaknya energi yang diserap (I /Intensitas) terhadap kuat medan magnet (Pavia, 2009).

\subsubsection{Spektrofotometri Massa}

Sampel dilarutkan dalam pelarut yang mudah menguap dan dinjeksikan dalam GCMS untuk dilihat berat molekul totalnya berdasarkan peak-peak spektra (Pavia, 2009).

\subsection{Uji In Vivo Aktivitas Antimalaria} Plasmodium Berghei (Uji Variasi Dosis)

Hewan coba yang digunakan adalah mencit jantan galur Swiss dengan berat 20-30 gram yang dirawat di Laboratorium Biomedik Fakultas Farmasi Universitas Jember. Hewan coba diberi pakan standar pellet jenis PL2P. Sebelum diberi perlakuan hewan coba diadaptasikan terhadap kondisi laboratorium selama 1 minggu. Ethical Clearance untuk hewan coba diperoleh dari Fakultas Kedokteran Universitas Jember. Mencit yang telah terinfeksi parasit $P$. berghei diberi senyawa (isolat tanaman Irvingia malayana) dengan berbagai variasi dosis. Pada uji ini mencit positif terinfeksi $P$. berghei dikelompokkan menjadi 6 kelompok perlakuan, masing-masing kelompok terdiri dari 5 mencit. Dosis yang digunakan adalah 1 , 10, dan $100 \mathrm{mg} / \mathrm{kg} \mathrm{BB}$. Pada uji variasi dosis juga digunakan kelompok kontrol negatif (CMC 1\%), sedang kontrol positif adalah klorokuin $25 \mathrm{mg} / \mathrm{kg} \mathrm{BB}$. Tingkat parasitemia awal dihitung dengan mengambil darah dari ekor untuk dibuat preparat apus seperti pada pemberian dosis tunggal. Selanjutnya setelah pemberian isolat, darah diambil setiap hari selama 4 hari berturut-turut untuk dibuat preparat apus dan dihitung tingkat parasitemianya (Anonim, 2016; Kim dkk, 2000). 
2.10 Uji In Vitro Aktivitas Antimalaria Plasmodium Falciparum

Aktivitas in vitro terhadap Plasmodium falciparum pada tahap intraerythrocytic isolat tanaman Irvingia malayana dengan cara Mark III tes, seperti yang dikembangkan oleh WHO. Strain $P$. falciparum FCR3 yang dibudidayakan dalam eritrosit baru dikumpulkan sebagai sel inang dalam media RPMI 1640 mengandung HEPES 25 mM dan 6,8 M hipoksantin ditambah dengan $0,5 \%$ AlbuMAX II. Kultur disimpan pada suhu $37^{\circ} \mathrm{C}$. Isolat tanaman Irvingia malayana dilarutkan dalam etanol atau dimetil sulfoksida (DMSO) dan diencerkan dalam RPMI. Mikro plate dititrasi dengan dua kali lipat pengenceran setiap isolat tanaman Irvingia malayana serta kontrol. Strain berlapis disinkronkan pada cincin-tahap parasit dengan parasitemia antara 0,6-0,8\% . Jumlah masing-masing terukur dengan baik yakni $10 \mu \mathrm{L}$ eritrosit yang mengandung parasit, hematokrit 5\%, dan $90 \mu \mathrm{L}$ pengenceran obat yang berbeda. Lempeng diinkubasi pada suhu $37^{\circ} \mathrm{C}$ selama 20-24 jam untuk disinkronikasi dengan dinyatakan positif terdapat schizonts matang dalam sumur sampel kontrol (tanpa obat). Kemudian dilanjutkan ke uji in vitro dengan mikroplate 96whell diinkubasi pada suhu $37^{\circ} \mathrm{C}$ selama 72 jam kemudian lempeng dikeluarkan dari candle jar. Sediaan uji dicampur homogen dan disentrifugasi filtrat dibuang dan bagian yang pekat dibuat sediaan apusan. Apusan dikeringkan pada suhu kamar dan difiksasi dengan metanol $80 \%$ dan setelah kering diwarnai dengan larutan giemsa $10 \%$ dalam aquades selama 30 menit. Evaluasi tiap sumuran baik untuk kontrol maupun sampel uji dihitung $\%$ parasetemia dengan membandingkan eritrosit terinfeksi parasit dari sekitar 1000 eritrosit. Hasil giemsa di mikroskop optik perbesaran 100 kali. Nilai $\mathrm{IC}_{50}$ dihitung dari kurva dosis-respon diamati (persentase schizonts vs logaritma dari konsentrasi sampel) dengan interpolasi linier. Klorokuin digunakan sebagai kontrol positif (Desjardins dkk, 1979).

$\%$ parasetemia $=$ parasetemia kontrol - parasetemia obat $/$ parasetemia kontrol x 100\%

\subsection{Analisis Data Uji Antimalaria}

Data yang diperoleh, dilakukan analisis statistik Anava satu arah dengan tingkat kepercayaan $95 \%(\alpha=0,05)$ dan dilanjutkan dengan LSD untuk melihat perbedaan bermakna antar kelompok dengan harga $\mathrm{p} \leq$ 0,05 untuk mengetahui pengaruh pemberian sampel (isolat Irvingia malayana) terhadap kontrol positif dan negatif.

\section{HASIL DAN PEMBAHASAN}

\subsection{Ekstraksi Tanaman Irvingia Malayana}

Ekstraksi dilakukan dengan cara perkolasi dan diulang 3 kali, filtrat yang diperoleh kemudian diuapkan pelarutnya 
dengan menggunakan rotary evaporator n-heksan, dan etil asetat ternyata berat ekstrak hingga diperoleh ekstrak kasar (Saxena dkk, yang paling banyak ada pada pelarut etanol 2003). Hasil ekstraksi akar, batang, dan daun yang bersifat polar yang ditunjukkan pada Irvingia malayana dalam pelarut etanol 70\%, Tabel 1.

Tabel 1. Hasil Ekstrak Akar, Batang, Dan Daun Irvingia malayana

\begin{tabular}{cccc}
\hline Sampel & Pelarut Etanol & Pelarut Etil asetat & Pelarut n-Heksan \\
\hline Akar & $3,3 \mathrm{~g}$ & $6,3 \mathrm{~g}$ & $1,1 \mathrm{~g}$ \\
Batang & $25,4 \mathrm{~g}$ & $6,8 \mathrm{~g}$ & $1,2 \mathrm{~g}$ \\
Daun & $71,4 \mathrm{~g}$ & $12,2 \mathrm{~g}$ & $8,6 \mathrm{~g}$ \\
\hline
\end{tabular}

3.2 Skrining Fitokimia Dari Akar, yang dicurigai sebagai antimalaria yaitu Batang, Dan Daun Tanaman Irvingia senyawa terpenoid positif sedangkan Malayana alkaloidnya negatif semua pada akar, batang

Skrining fitokimia yang dilakukan dan daun. Hasil skrining senyawa terpenoid bertujuan untuk menentukan golongan paling banyak ada pada batang pada ekstrak metabolit sekunder yang mempunyai aktivitas etil asetat. Hasil skrining fitokimia dapat biologis yang ada dalam akar, batang, dan dilihat Tabel 2. daun tanaman Irvingia malayana ternyata

Tabel 2. Hasil Skrining Fitokimia Tanaman Irvingia malayana

\begin{tabular}{|c|c|c|c|c|c|c|c|}
\hline \multirow{2}{*}{ No } & \multirow{2}{*}{ Sampel } & \multirow{2}{*}{ Pelarut } & \multicolumn{5}{|c|}{ Skrining fitokimia } \\
\hline & & & Flavonoid & Fenol & Terpenoid & Alkaloid & Antrakinon \\
\hline \multirow{3}{*}{1} & \multirow{3}{*}{ Daun } & Etil asetat & + & + & + & - & - \\
\hline & & Heksan & + & + & + & - & - \\
\hline & & Etanol & + & + & + & - & - \\
\hline \multirow{3}{*}{2} & \multirow{3}{*}{ Batang } & Etil asetat & + & + & + & - & + \\
\hline & & Heksan & + & + & + & - & + \\
\hline & & Etanol & + & + & + & - & + \\
\hline \multirow{3}{*}{3} & \multirow{3}{*}{ Akar } & Etil asetat & + & + & + & - & + \\
\hline & & Heksan & + & + & + & - & + \\
\hline & & Etanol & + & + & + & - & + \\
\hline
\end{tabular}

\subsection{Uji Kemurnian Senyawa Hasil Isolasi}

Pada uji kemurnian senyawa hasil sintesis dilakukan dengan metode KLTdensitometri dengan purity dan penentuan titik leleh. Uji kemurnian dengan titik leleh dapat dilihat pada Tabel 3.
Tabel 3. Hasil Uji Jarak Lebur Senyawa Hasil Isolasi

\begin{tabular}{cc}
\hline No & Jarak lebur $\left({ }^{\circ} \mathbf{C}\right)$ \\
\hline 1. & $120-121^{\circ} \mathrm{C}$ \\
2. & $120-121^{\circ} \mathrm{C}$ \\
3. & $120-121^{\circ} \mathrm{C}$ \\
\hline Rata-rata & $120-121^{\circ} \mathrm{C}$ \\
\hline
\end{tabular}


Pada metode KLT, hasil isolasi dieluasi dengan komposisi pelarut yang berbeda polaritasnya. Setelah dilakukan optimasi maka eluen yang dapat memisahkan beberapa fraksinasi yaitu eluen heksan:etil asetat (3:2) dan eluen yang dapat memisahkan isolat yaitu diklormetan:metanol (10:1) dimana Rf 0,6 dan sesuai literature antara 0,2-0,8 dapat dilihat pada gambar 2 (10). Adanya satu noda yang berbeda Rf pada lempeng KLT setelah disinari lampu UV $254 \mathrm{~nm}$ menunjukkan bahwa hasil tersebut merupakan senyawa tunggal. Uji kemurnian dengan KLTDensitometri dengan purity test menunjukkan senyawa adalah murni (ok) dengan $r=0.995$ yang dapat dilihat pada Gambar 2 dan 3.
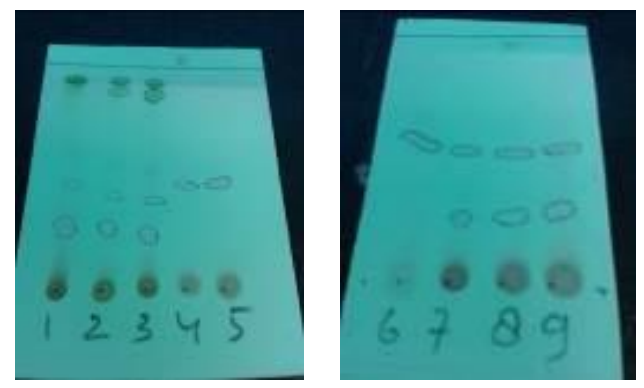

Keterangan :

1. Daun etanol

2. Daun Etil asetat

3. Daun Heksan

4. Batang Etanol

5. Batang Etil Asetat

6. Batang Heksan

7. Akar Etanol

8. Akar Etil Asetat

9. Akar Heksan

Gambar 2. Hasil KLT skrining fitokimia dengan eluen optimasi heksan:etil asetat (3:2)
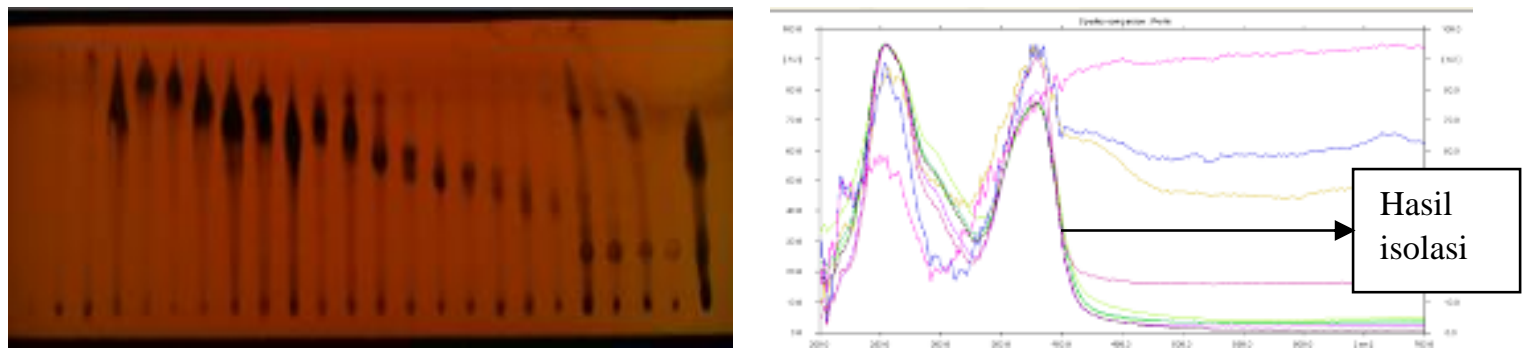

Gambar 3. Uji purity dengan KLT isolat tanaman Irvingia malayana dengan purity test murni (ok) dengan $r=0.995$ (lebih dari 0,9)

Setelah dilakukan uji purity dimana senyawa hasil isolasi murni maka selanjutnya

\subsection{Identifikasi Struktur Senyawa Hasil} Isolasi

FTIR Dan H NMR Senyawa Hasil

\section{Isolasi}

Pada spektrum IR senyawa hasil isolasi terdapat puncak pada daerah bilangan gelombang $1639 \mathrm{~cm}^{-1}$ yang menunjukkan adanya gugus karbonil amida $(\mathrm{N}-\mathrm{C}=\mathrm{O})$, amin primer stretching pada $3418 \mathrm{~cm}^{-1}$ dan ikatan dilakukan identifikasi struktur dengan FTIR, H NMR dan GC-MS.

rangkap $\mathrm{C}=\mathrm{C}$ aromatis di daerah sekitar 2935 $\mathrm{cm}^{-1}$ dan $1465 \mathrm{~cm}^{-1}$. Ikatan aromatis osubstitusi benzena ada pada bilangan gelombang $801 \mathrm{~cm}^{-1}$. Spektrum pada 1384 $\mathrm{cm}^{-1}$ menunjukkan ikatan isopropil dan terbutil (Pavia, 2009). Spektrum FTIR dan H NMR senyawa isolasi dapat dilihat pada Gambar 4 dan 5. 


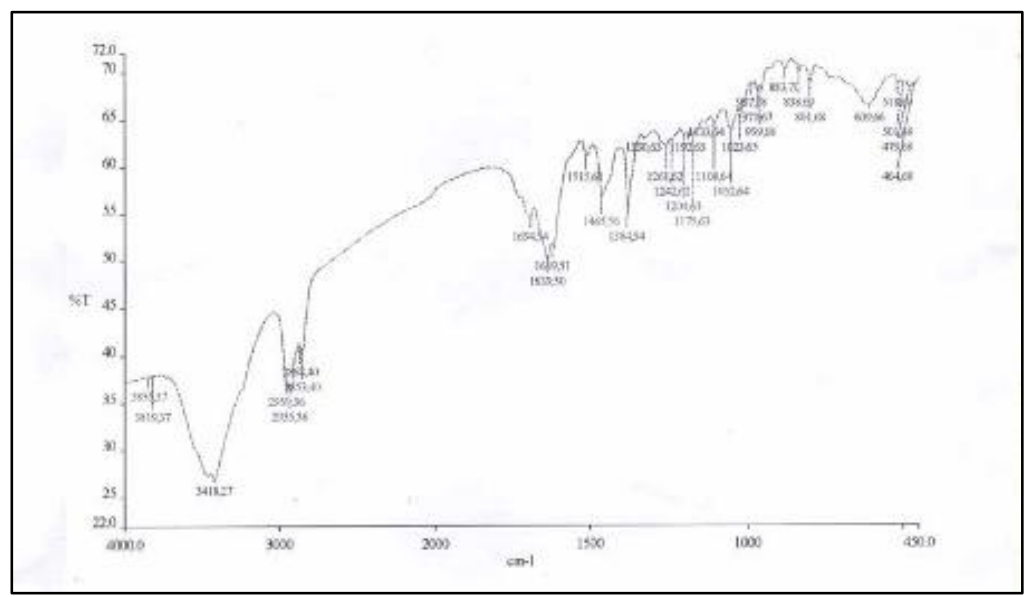

Gambar 4. Spektra FTIR senyawa hasil isolasi

Tabel 4. Karakteristik Spektrum FTIR Hasil Isolasi

\begin{tabular}{ccc}
\hline Tipe Vibrasi & Frekuensi $\mathbf{( \mathbf { c m } ^ { - 1 } )}$ dari & Frekuensi $\mathbf{( \mathbf { c m } ^ { - 1 } ) \text { dari }}$ \\
\hline N primer & $3500-3100$ & 3418 \\
CH alkil & $2853-2962$ & 2853,2935 \\
C=C aromatis & $1600-1475$ & 1465 \\
orto-substitusi benzen & $800-700$ & 801 \\
C=O Amida & $1680-1630$ & 1639 \\
C-H isopropyl, ter-butil & $1365-1395$ & 1384 \\
\hline
\end{tabular}

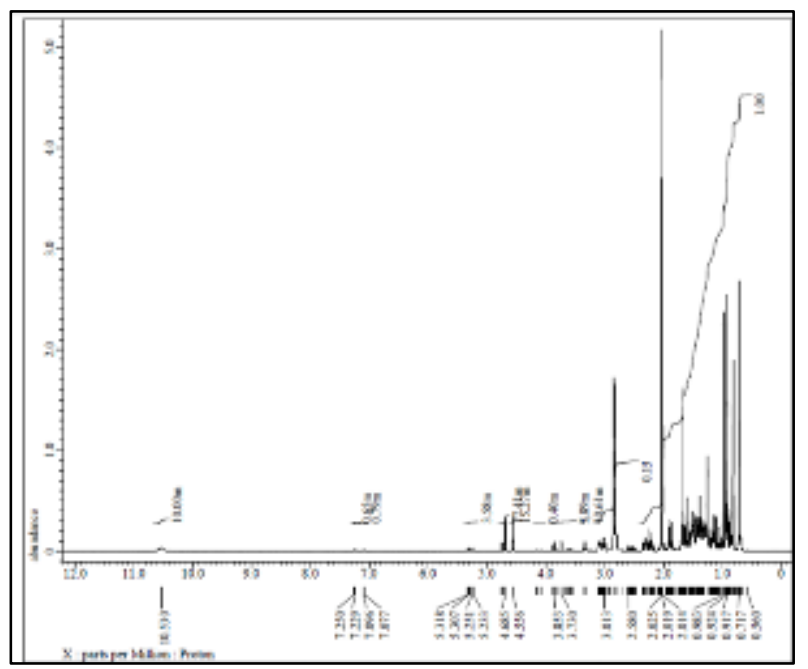

Gambar 5. Spektra H-NMR senyawa hasil isolasi

Tabel 5. Karakteristik Spektrum Proton NMR Senyawa Hasil Isolasi

\begin{tabular}{cccc}
\hline Pergeseran kimia & Perbandingan & Multiplisitas & Proton dari gugus \\
\hline 10,5 & 10 & Singlet & H amin \\
$7,0-7,2$ & 12 & Doublet & H aromatis \\
$5,2-5,3$ & 4 & Doublet & H alkena \\
$4,5-4,6$ & 32 & Multiplet & H alkil \\
$3,0-3,8$ & 16 & Multiplet & H alkil \\
\hline & Total & & $\mathbf{7 4}$
\end{tabular}


3.5 Spektrofotometri Massa (GC-MS) molekul totalnya berdasarkan peak-peak Senyawa Hasil Isolasi spektra pada hasil. Spektrum GC-MS Sampel dilarutkan dalam aseton dan senyawa hasil isolasi dapat dilihat pada dinjeksikan dalam GC-MS untuk dilihat berat Gambar 6.

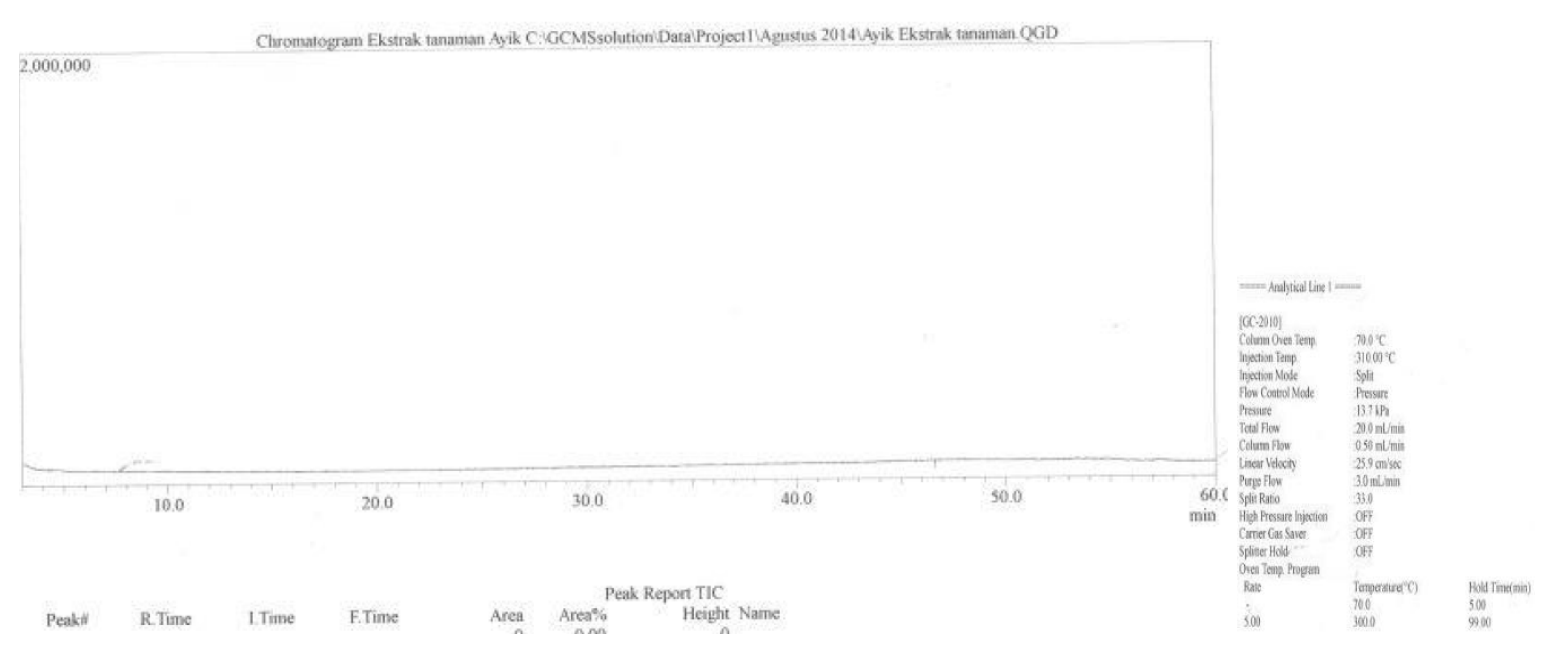

Gambar 6. Kromatogram GC-MS senyawa hasil isolasi

Dari gambar terlihat bahwa senyawa tidak dapat diketahui berat molekulnya dikarenakan sampai suhu $310^{\circ} \mathrm{C}$ belum teridentifikasi karena terlalu tinggi titik didihnya. Dari Hasil identifikasi struktur disimpulkan bahwa senyawa hasil isolasi adalah golongan terpenoid batang Irvingia malayana pada ekstrak etil asetat dan termasuk golongan silimarin seperti halnya 3.6 Uji In Vivo Aktivitas Antimalaria Plasmodium Berghei

Hasil uji antimalaria secara in vivo mencit positif terinfeksi $P$. berghei dikelompokkan menjadi 5 kelompok perlakuan, masing-masing kelompok terdiri dari 3 mencit. Dosis yang digunakan adalah 1, 10, dan $100 \mathrm{mg} / \mathrm{kg}$ BB. Pada uji variasi dosis juga digunakan kelompok kontrol negatif tanaman lain dalam genus Irvingia (Donfack dkk, 2010; Ikhatua dan Falodun, 2012).

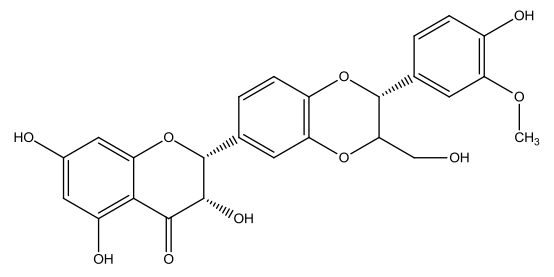

Gambar 7. Struktur kimia silimarin

(CMC 1\%), sedang kontrol positif adalah klorokuin $25 \mathrm{mg} / \mathrm{kg} \mathrm{BB}$. Tingkat parasitemia awal dihitung dengan mengambil darah dari ekor untuk dibuat preparat apus dan setelah pemberian isolat, darah diambil setiap hari selama 4 hari berturut-turut untuk dibuat preparat apus dan dihitung tingkat parasitemianya. Berikut Tabel 6 dan Gambar 
Studi Fitokimia Irvingia Malayana....

8 data hasil parasetemia dan $\mathrm{IC}_{50}$ uji in vivo isolat Irvingia malayana

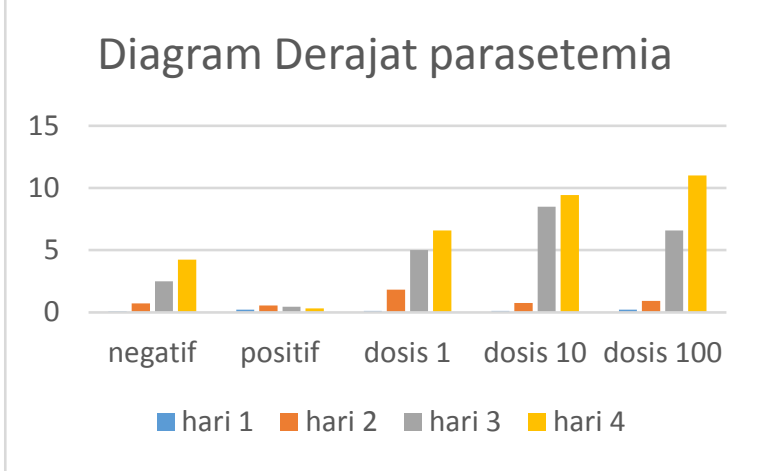

Gambar 8. Diagram derajat parasetemia uji antimalaria in vivo isolat Irvingia malayana
Tabel 6. Data $\mathrm{IC}_{50}$ Uji In Vivo Antimalaria Isolat Irvingia malayana

\begin{tabular}{cc}
\hline Hari & IC $_{\mathbf{5 0}}(\mathbf{m g} / \mathbf{k g B B})$ \\
\hline 0 & 32.360 \\
1 & - \\
2 & 25.781 \\
3 & 6.927 \\
4 & 11.827 \\
\hline
\end{tabular}

3.7 Uji In Vitro Aktivitas Antimalaria Plasmodium Falcifarum

Hasil uji in vitro antimalaria/antiplasmodium menggunakan Plasmodium falcifarum FCR3 dapat dilihat pada Gambar 9 dan 10.

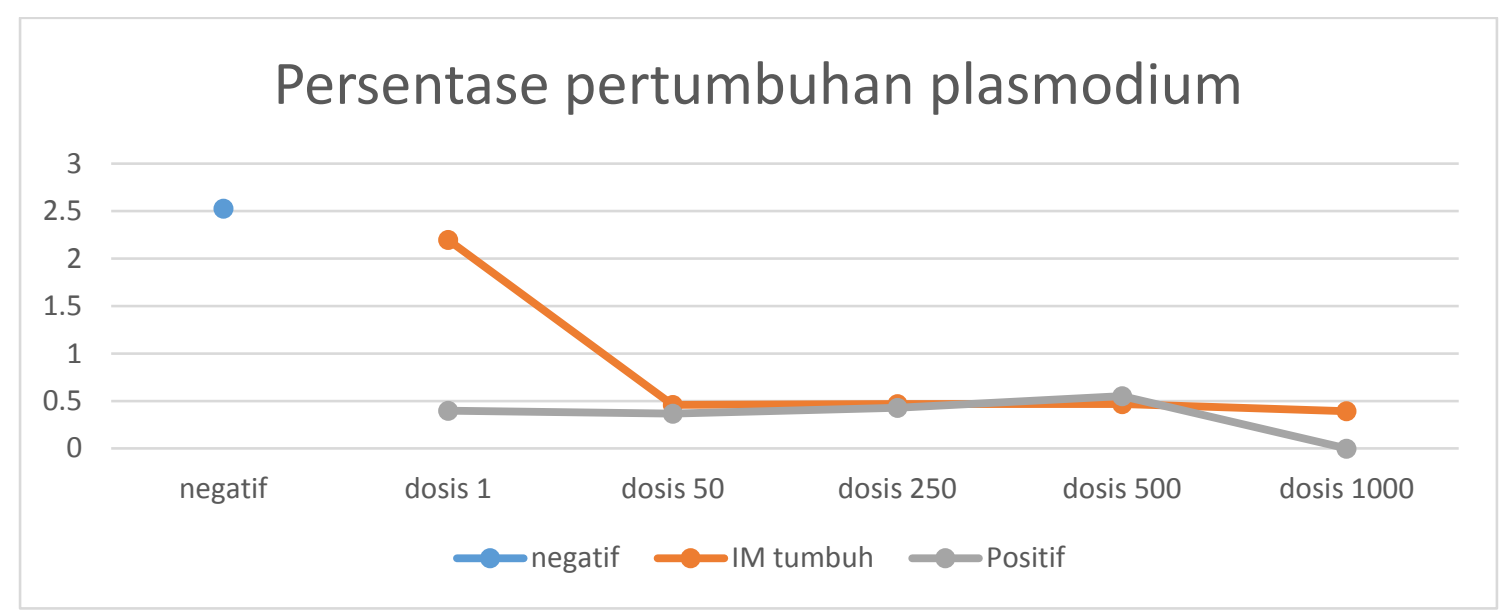

Gambar 9. Diagram persentase pertumbuhan Plasmodium falcifarum setelah diberi isolat Irvingia malayana (IM) dan kontrol positif (klorokuin)

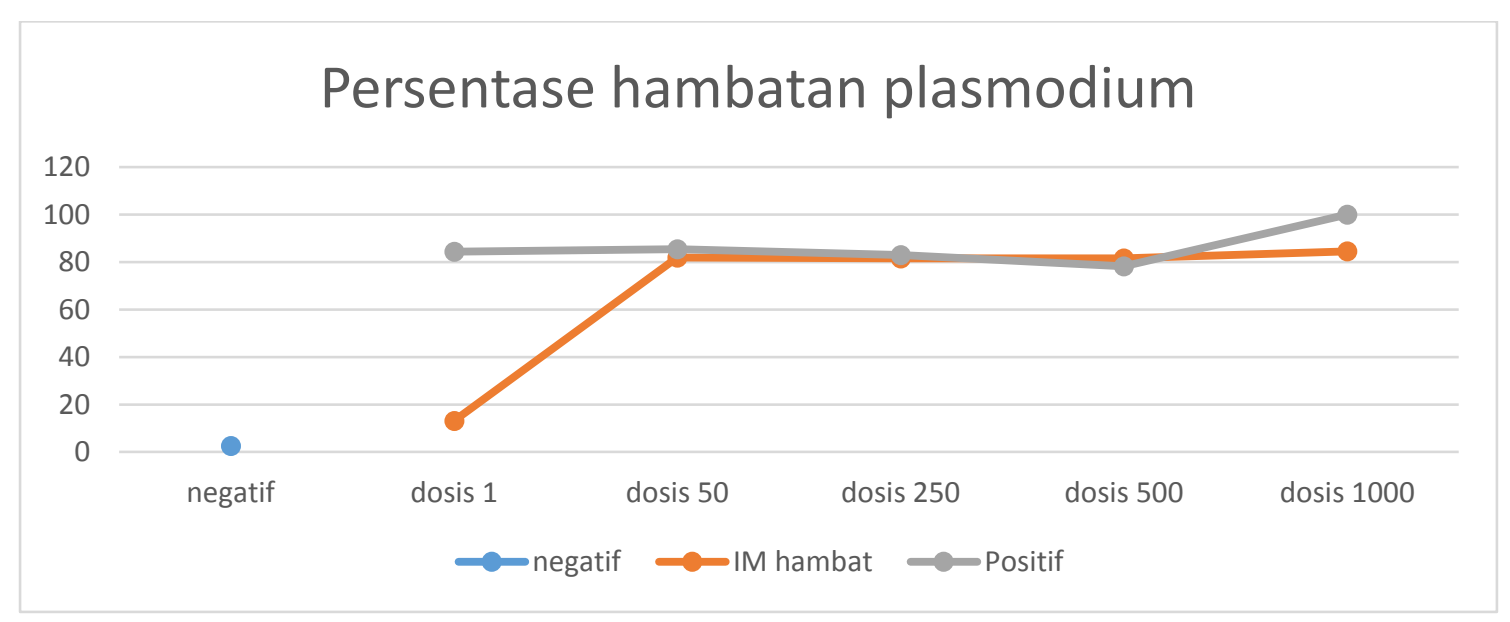


Gambar 10. Diagram persentase hambatan Plasmodium falcifarum setelah diberi isolat Irvingia malayana (IM) dan kontrol positif (klorokuin)

Tabel 7. Data $\mathrm{IC}_{50}$ Uji In Vitro Antimalaria Isolat Irvingia malayana

\begin{tabular}{ll}
\hline Senyawa & IC50 $(\boldsymbol{\mu g} / \mathbf{m l})$ \\
\hline Isolat Irvingia malayana & 62,855 \\
Klorokuin & $1,114 \times 10^{-3}$ \\
\hline
\end{tabular}

Hasil ekstraksi yang dilakukan didapatkan rendemen yang dapat dilihat di Tabel 1. Selanjutnya dilakukan isolasi dengan kromatografi kolom dan di analisis menggunakan KLT-Densitometri (Gambar 2 dan 3) didapatkan isolat 15-19 dari 23 fraksi yang memiliki kemurnian tinggi (1 noda), didapatkan rendemen murni $50 \mathrm{mg}$ sekitar $0.1 \%$ dari ekstrak etil asetat pada batang Irvingia malayana. Selanjutnya isolat 17-19 tersebut dianalisis untuk dielusidasi struktur menggunakan FTIR dan H-NMR untuk mengetahui strukturnya. Identifikasi struktur menggunakan pelarut aseton deuterium dengan standar internal TMS (tetrametilsilina). Hasil Identifikasi struktur menunjukkan hasil isolasi merupakan golongan terpenoid dari batang Irvingia malayana pada ekstrak etil asetat dan termasuk golongan silimarin seperti halnya tanaman lain dalam genus Irvingia yang didukung dengan spektra FTIR dan H NMR yang ditunjukkan pada Tabel 4 dan 5 (Pavia, 2009). Perbandingan integrasi H-NMR isolat Irvingia malayana pada Tabel 5 memberikan jumlah atom hidrogen dalam senyawa yang diuji dengan jumlah proton 74 yang menunjukkan golongan silimarin terpolimerasi dengan bentuk kristal putih (Donfack dkk, 2010; Ikhatua dan Falodun, 2012; Pavia, 2009). Titik lebur isolat yaitu $120-121^{\circ} \mathrm{C}$ dan merupakan senyawa yang murni dengan jarak lebur $\leq 2^{\circ} \mathrm{C}$ (Jayaselli dkk, 2008).

Berdasarkan analisis anova one way pada uji antimalaria in vivo menunjukkan bahwa masing masing kelompok berbeda bermakna. Hal ini dikarenakan data biologis in vivo memberikan hasil cukup kompleks. Uji statistik probit untuk mendapatkan $\mathrm{IC}_{50}$ masing masing hari. Pada hari 4 setelah pemberian menunjukkan $\mathrm{IC}_{50} \quad 11.827$ $\mathrm{mg} / \mathrm{kgBB}$ dibandingkan hari $3 \quad 6.927$ $\mathrm{mg} / \mathrm{kgBB}$ ) yang artinya aktivitas malarianya lebih baik pada hari 3 daripada hari 4 . Hari ke 3 adalah maksimal lama pemberian yang memberikan efek maksimum daripada hari selanjutnya dalam menurunkan plasmodium (Gambar 8, 9, dan 10). Berdasarkan klasifikasi IC I0 $_{50} 6.927$ mg/kgBB menunjukkan sangat baik aktivitas antimalaria. $\mathrm{IC}_{50}$ adalah konsentrasi yang membunuh 50\% Plasmodium setelah diberi sampel uji dimana klasifikasinya $\mathrm{IC}_{50}$ konsentrasi $\leq 10 \mu \mathrm{g} / \mathrm{ml}$ sangat baik aktivitasnya, $10-50 \mu \mathrm{g} / \mathrm{ml}$ aktivitas sedang, dan $>50 \mu \mathrm{g} / \mathrm{ml}$ sangat lemah aktivitasnya (Fidock dkk, 2004; Gessler dkk, 1994). 
Dari hasil uji in vitro antimalaria/antiplasmodium dilakukan analisis probit didapatkan $\mathrm{IC}_{50}$ isolat Irvingia malayana yaitu $62,855 \mu \mathrm{g} / \mathrm{ml}$ dimana berdasarkan klasifikasinya memiliki aktivitas antiplasmodium lemah jika dibandingkan kontrol positif klorokuin $\left(\mathrm{IC}_{50}=1,114 \times 10^{-3} \mu \mathrm{g} / \mathrm{ml}\right)$ yang ditunjukkan pada Tabel 7. Hal ini dikarenakan proses pencarian isolat tidak berdasarkan Bioassay guided selama proses isolasi namun berdasarkan jumlah mayor senyawa murni yang ada dalam tanaman yaitu batang

\section{KESIMPULAN}

Senyawa hasil isolasi adalah senyawa terpenoid pada batang dari ekstrak etil asetat merupakan golongan silimarin seperti halnya tanaman lain dalam genus Irvingia. Jarak lebur isolat Irvingia malayana yaitu 120$121{ }^{\circ} \mathrm{C}$ berbentuk kristal putih. Pada Uji in vivo menunjukkan bahwa masing masing kelompok berbeda bermakna. Pada hari 4 setelah pemberian menunjukkan $\mathrm{IC}_{50}$ yaitu $11,827 \mathrm{mg} / \mathrm{kgBB}$ dibandingkan hari $3(6,927$ $\mathrm{mg} / \mathrm{kgBB}$ ). Hari ke 3 adalah maksimal lama pemberian yang memberikan efek maksimum daripada hari selanjutnya dalam menurunkan plasmodiumnya dengan klasifikasi sangat baik aktivitasnya sebagai antimalaria. Dari hasil uji in vitro didapatkan $\mathrm{IC}_{50}$ isolat Irvingia malayana yaitu $62,855 \mu \mathrm{g} / \mathrm{ml}$ dan berdasarkan klasifikasinya memiliki aktivitas antiplasmodium lemah jika dibandingkan kontrol positif klorokuin $\left(\mathrm{IC}_{50}=1,114 \times 10^{-3}\right.$ tanaman Irvingia malayana sehingga meskipun jumlah mayor senyawa murninya namun ternyata pada aktivitas antiplasmodiumnya secara in vitro lebih kecil dibandingkan dengan klorokuin sebagai kontrol positif. Berdasarkan data uji aktivitas in vivo dan in vitro antimalaria menunjukkan bahwa isolat kurang memberikan aktivitas antimalaria dikarenakan pada ekstrak yang terdiri dari komponen yang cukup banyak kemungkinan ada mekanisme kerja obat antimalaria secara sinergisme dibandingkan isolat yang terdiri dari senyawa tunggal.

$\mu \mathrm{g} / \mathrm{ml})$. Berdasarkan data uji aktivitas in vivo dan in vitro antimalaria menunjukkan bahwa isolat kurang memberikan aktivitas antimalaria.

\section{UCAPAN TERIMA KASIH}

Terima kasih kepada Universitas Jember melalui DP2M Tahun Anggaran 2015 dan 2016 yang telah mendanai Program Penelitian Desentralisasi Hibah Bersaing ini.

\section{DAFTAR PUSTAKA}

Aguiar, A.C.C, Rocha, E.M.M, Souza, N.B, França, T.C.C, Krettli, A.U. New Approaches in Antimalarial Drug Discovery and Development-A Review. Mem Inst Oswaldo Cruz. 2012; 107(7): 831-845

Anonim. Laboratory for experimental botany, University of LJUBLJAWA, Slovenia. 2016.

http://botanika.biologija.org/exp/comet/, accessed on 6 Juni 2016

Beourou, S, Le Lamer, A.C, MaurelChevalley, S, Mutiso, P.B.C, Souard, F, Moulis, C, Fabre, N, Valentin, A. Evaluation of the Antiplasmodial Activity of Extracts of Plants Used in Traditional 
Medicine in Kenya. Brazilian Journal of Pharmacognosy. 2011; 21(6) : 986-990

Bero, J, Richb, M.F and Quetin-Leclercq, J. Antimalarial Compounds Isolated from Plants Used in Traditional Medicine. Journal of Pharmacy and Pharmacology. 2009; 61: 1401-1433

Bunnag D, Kanda T, Karbwang J, Thimasarn $\mathrm{K}$, Pungpak S. Two doses of artemether/mefloquine or artesunate/mefloquine combination for multidrug resistant Falciparum malaria. Southeast As J Trop Med Pub Health. 1997; 28: 727-35

Centers for Disease Control and Prevention. Where Malaria Occurs. 2010. http://www.cdc.gov/malaria/about/distrib ution.html. Accessed on 29 September 2012

Chinchilla, M, Valerio, I, Sanchez, R, Mora, V, Bagnarello, V, Martinez, L, Gonzalez, A, Vanegas, J.C and Apestegui, A. In Vitro Antimalarial Activity of Extracts of Some Plants from a Biological Reserve in Costa Rica. Rev. Biol. Trop. (Int. J. Trop. Biol.). 2012; 60 (2): 881-891

Desjardins, R. E., Canfield, C. J., Haynes, J. D., Chulay, J. D. Quantitative assessment of antimalarial activity in vitro by a semiautomated microdilution technique. Antimicrob. Agents Chemother.1979; 16: 710-718

Direktorat Pengendalian Penyakit Bersumber Binatang. Epidemiologi di Indonesia. Buletin Jendela Data dan Informasi Kesehatan. 2011; 1: 1 - 16.

Donfack, J.H., Fotso, G.W., Ngameni, B., Tsofack, F.N., Tchoukoua, A., Ambassa, P., Abia, W., Tchana, A.N., Giardina, S., Buonocore, D., Finzi, P.V., Vidari, G., Marzatico, F., Ngadjui, T., and Moundipa, P.F. In Vitro Hepatoprotective And Antioxidant Activities of The Crude Extract And Isolated Compounds From Irvingia Gabonensis. Asian Journal of Traditional Medicines. 2010; 5 (3): 79-88

Fidock, D.A., Rosenthal, P.J., Croft, S.L., Brun, R., Nwaka, S. Antimalarial drug discovery: Efficacy models for compounds screening, Nature Reviews Drug Discovery. 2004; 3: 509-520

Gessler, MC., Nkunya, M.H.N., Nwasumbi, L.B., Heinrich, M. and Tonner, M. Screening Tanzanian medical plants for antimalarial activity. Acta Tropica. 1994; 55: 65-67

Ikhatua, M.I and Falodun, A. The Essential Oil Components Of Irvingia Gabonensis And Irvingia wombolu From Southern Nigeria. Canadian Journal of Pure and Applied Sciences. 2012; 6(2): 1955-1959

Jayaselli, Chemala, Rani, dan Serbani. Derivatization of Enolic OH of Piroxicam: a Comparative Study on Esters and Sulfonates. J. Braz. Chem. Soc. 2008; 19 (3): 509-515.

Kim H-S., Shibata Y., Ko N., Ikemoto N., Ishizuka Y., Murakami N., Sugimoto, M., Kobayashi M., Wataya Y. Potent in-vivo antimalarial activity of 3,15-di-Oacetylbruceolide against Plasmodium berghei infection in mice. Parasitology International. 2000; 48 :271-274.

Pavia, Lampman, Kriz, dan Vyvyan. Introduction to Spectroscopy Fourth Edition. 2009. USA: Cengage Learning Inc.

Phillipson J.D., Wright C.W., Kirby G.C., Warhurst D.C. Phytochemistry of some plants used in traditional medicine for the treatment of protozoal diseases, In : Phytochemstry of Plants Used in Traditional Medicine. 1995. Ed : Hostettmann K., Marston A., Maillard M and Hamburger $M$. Oxford Science Publications, Oxford.

Pouplin. J. N. and Tran. H. Antimalarial and Citotoxic Activities of Ethnopharmacologically Selected Medical Plants from South Vietnam. J. Ethnopharm. 2007; 109 (2): 417-427.

Praptiwi dan Chairul. Pengaruh Pemberian Ekstrak Pauh Kijang (Irvingia malayana Oliv. ex. A. Benn) Terhadap Tingkat Penurunan Parasitemia pada Mencit yang Diinfeksi Plasmodium berghei. Biodiversitas. 2008; 9 (2): 96-98

Santoso. Evaluasi Penggunaan ArtesunatAmodiakuin (Artesdiakuin) Pada 
Pengobatan Malaria Tanpa Komplikasi Di Puskesmas Penyandingan Dan Tanjung Lengkayap Kabupaten Oku. 2011. http://ejournal.litbang.depkes.go.id/index. $\mathrm{php} / \mathrm{BPK} / \mathrm{article} / \mathrm{view} / 73$. Accessed on 26 April 2013.

Saxena, S, Pant, N, Jain, D.C, and Bhakuni, R.S. Antimalarial Agents from Plant Sources. Current Science. 2003; 85: 9

Syamsudin. Mekanisme Kerja Obat Antimalaria. Jurnal Ilmu Kefarmasian Indonesia. 2005; 3(1): 37-40

Tjitra E. Obat anti malaria. Dalam: Harijanto PN, penyunting. Malaria epidemiologi, patogenesis, manifestasi klinis, dan penanganan. Jakarta: ECG. 2000; 195223.

World Health Organization . Malaria. 2011. http://www.who.int/topics/malaria/en/. Accessed on 29 September 2012

Wright ${ }^{\mathrm{a}}$, CW. Traditional antimalarials and the development of novel antimalarial drugs. J. Of Ethnopharmacology. 2005; 100: 67-71.

Wright $^{\mathrm{b}}$, C.W. Plant Derived Antimalarial Agents: New Leads and Challenges. Phytochemistry Reviews. 2005; 4: 55-61 